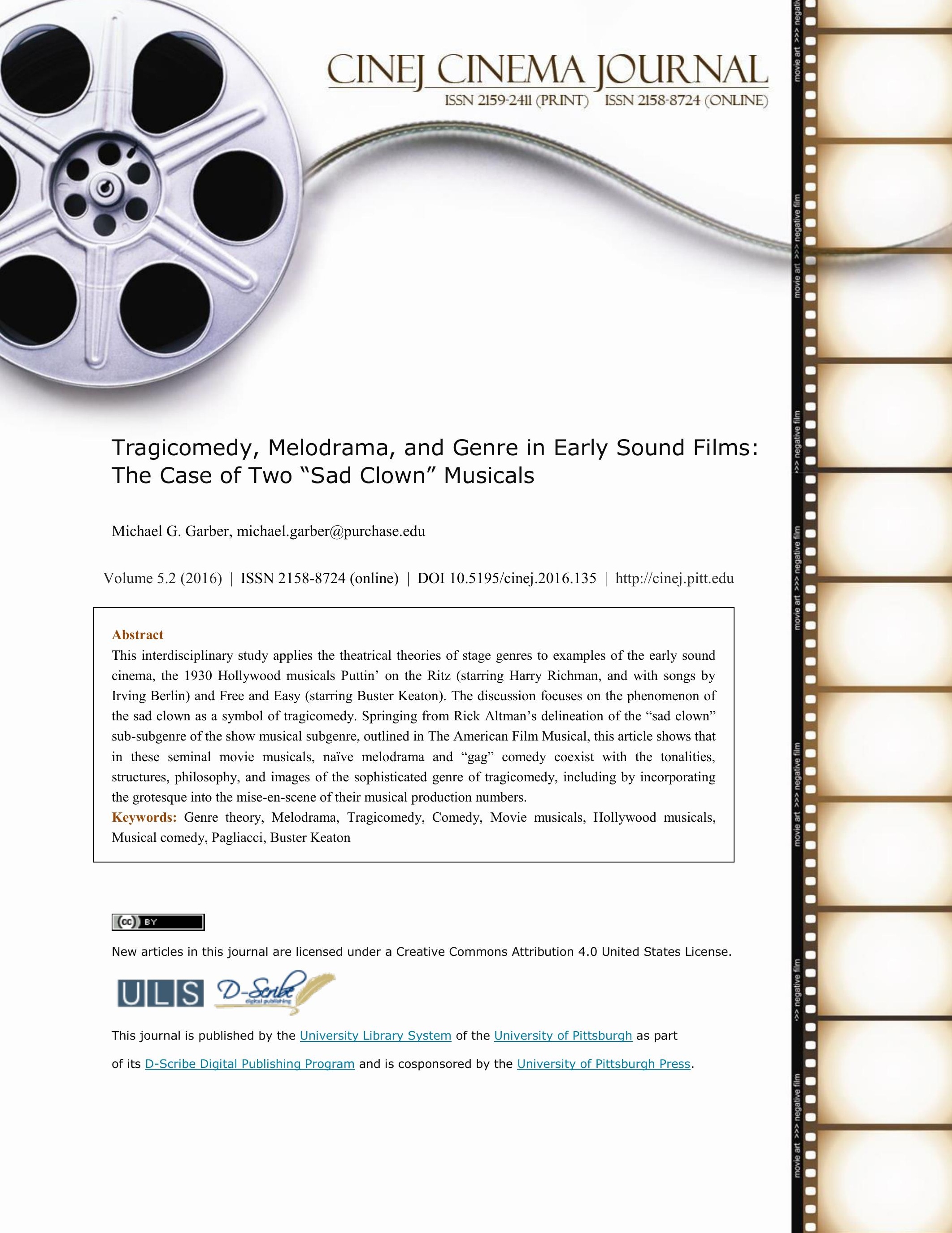




\section{Tragicomedy, Melodrama, and Genre in Early Sound Films: The Case of Two "Sad Clown" Musicals}

\section{Michael G. Garber}

Laughing on the outside, crying on the inside, a sad clown is a metaphor for the tragicomic view of life. The sad clown's dilemma captures the quintessence of the concept that everybody is a performer on the stage of society: each one must fulfill a role in the comedy of life, no matter how deeply hurt onstage or off - and, no matter how insane the rules that society dictates, the game must be played. (Figure 1.) As Wolfgang Kayser describes in his discussion of the romantic grotesque and tragicomedy, this is "an unimpassioned view of life on earth as empty, meaningless puppet play" (Kayser 1963, 186). In this worldview, the sad clown's poignant situation becomes relevant to all people, no matter what their walk in life.

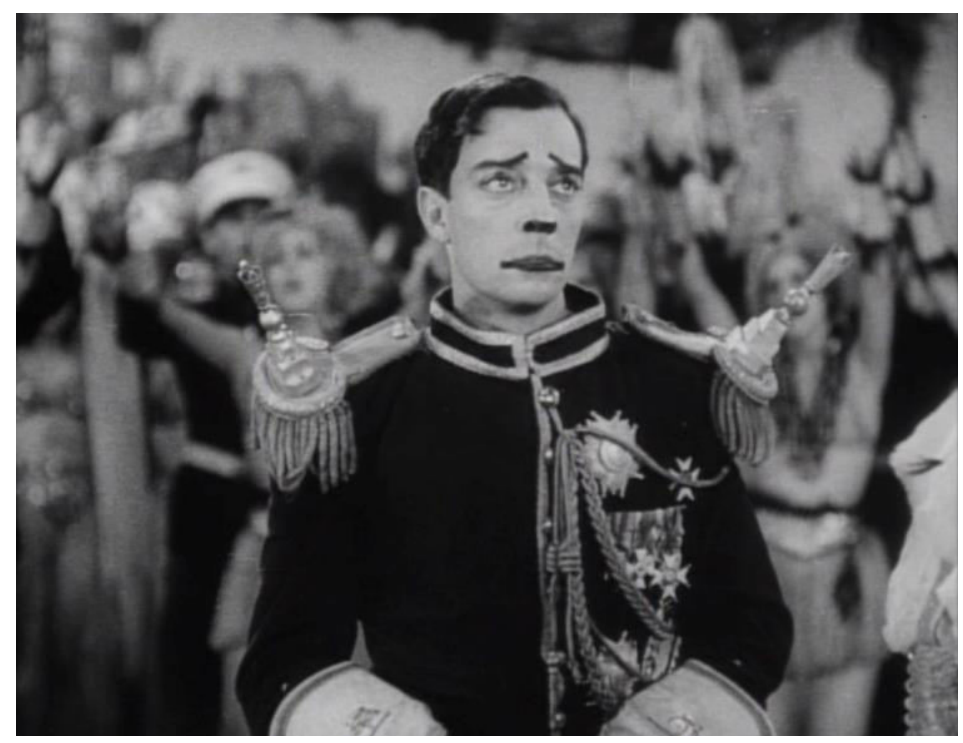

Figure 1. In Free and Easy (Edward Sedgwick, 1930), Elmer (Buster Keaton) must perform comedy in clown-like whiteface even while his heart is breaking. 


\section{The "Sad Clown" Musical}

In his analytic tome, The American Film Musical, Rick Altman describes a subgenre he calls the show musical, through which the audience peers into the depths of the creative process (Altman 1987, 210-2). He outlines two plot patterns for the show musical, that of the "sad clown" and that of the "happy clown" (ibid, 228). Historically, the sad clown type arose with the coming of sound to film, in 1927, and faded from prominence by mid-1933 (ibid, 211). By then, the happy clown plot had consolidated its popularity: in this, creativity arises alongside the joy of romantic union. Decades later, however, the happy clown stereotype becomes challenged. Once again, filmmakers depict the deep despair of their entertainerprotagonists. From the mid-1950s, the sad clown returns in movie musicals, but in a more selfconscious and intellectually sophisticated context (ibid, 261-71).

Jane Feuer and other film scholars have described how musicals create a desire in the audience to sing and dance joyfully by manipulating plot patterns and mise en scene - and by utilizing elements of long-standing, well-established entertainment traditions (Feuer 1993, 13-22, 53; Altman 1987, 344-59; Wolf 2002, 33). Sad clown musicals, however, problematize the exuberant expressions found in popular music (Feuer 1993, 107-22). These serious musicals undermine the belief in the unity of emotional experience and artistic expression.

An examination of the sad clown musicals using the lenses of genre theories of melodrama and, especially, tragicomedy, reveals more about their poignancy and the sophistication of their mixed moods. Despite the surge of serious analysis of both stage and film musicals during the last thirty years, very seldom have the theories of stage drama been applied to the movie musical. The following interdisciplinary analysis reveals the links between these two media, united as they are in both transmitting stories in the form of drama,

CINEJ Cinema Journal: Tragicomedy, Melodrama, and Genre in Early Sound Films

Volume 5.2(2016) ｜ＩSSN 2158-8724 (online) ｜ DOI 10.5195/cinej.2016.135 | http://cinej.pitt.edu 
and also helps highlight the idiosyncratic aesthetics and therefore the value of the Hollywood musical genre.

This article explores tragicomic dimensions in two early Hollywood musicals, Puttin' on the Ritz (Edward H. Sloman, 1930) and Free and Easy (Edward Sedgwick, 1930). For this examination, I will borrow from the work of Robert Henke to distinguish between the "tragicomic" and the "tragicomedic" (Henke 1997, 16-7). Tragicomic refers to the tone and mood of tragicomedy; tragicomedic refers to the narrative structures of tragicomedy - the elements characteristic of tragicomedy and the ways these elements are ordered into truly tragicomedic narratives.

Neither Puttin' on the Ritz nor Free and Easy is a tragicomedy. Nevertheless, they both take on tragicomic modes at various points in their unfolding. Both are, at their essence, musicals. As Altman points out in his analysis of that genre, these movies focus on the mating of a male and female who embody different traits (Altman 1987, 28-58). This couple is created and affirmed through music making - in the instance of these two films, through the mechanics of the entertainment business (ibid, 37-44, 124-8, 200-50). Within both films, show business is valorized - and concomitant with that valorization, the musical numbers in both movies are long, uninterrupted, of high quality, and are presented with visual clarity. The filmmakers engage us in these musical numbers through careful combinations of casting, musical arrangements and performance, camera framing, and mise en scene.

Both films feature tragicomic moments and, accompanying these, elements of tragicomedic structure, as if they adhered together. (That may seem to be stating the obvious, but the tragicomic need not necessarily accompany the tragicomedic in the show musical. Light humor and tragic disintegration can coincide in a musical without introducing any elements of 
action or mise en scene other than those appropriate to the comic or melodramatic genres from which the musical commonly borrows.) In Puttin' on the Ritz, we find a version of the "fortunate fall" that Jackson I. Cope writes of as being so prevalent in Renaissance tragicomedies (Cope 1973, 238, 261, 265-6). Both films incorporate tragicomedic elements in their musical production numbers: the royal court intruded upon by a commoner; odd settings, representing a kind of mysterious "nowhere"; and most, of all, various manifestations of the supernatural, the unexplained, the grotesque - in Puttin' on the Ritz, of the macabre and the dream and, in Free and Easy, the image of the magic clown.

\section{Puttin' on the Ritz}

Both Puttin' on the Ritz and Free and Easy were released in the spring of 1930, when sound film had crystallized as the new norm for Hollywood, yet the aesthetics of the newly audible medium were still in flux. The market was glutted with movie musicals, which by the summer of 1930 led to that genre temporarily falling out of favor with the mass audience. Ritz introduced movie fans across the nation to Harry Richman, long a favorite of New York vaudeville and cabaret - for many years Richman ran his own Manhattan nightclub. Although radio was soon to bring him to a widespread audience, Richman's national movie stardom never consolidated - a failure similar to that of many other stage favorites brought to Hollywood in the first years of sound, such as Marilyn Miller, Gertrude Lawrence, Fanny Brice, Sophie Tucker, George Jessel, and Frank Fay. Three of the songs for Puttin' on the Ritz were written by the iconic Tin Pan Alley songwriter, Irving Berlin: the rhythmically driving title song (still a favorite today, thanks to updatings and revivals) and the love ballad, "With You," both of which became hits, as well as a previously existing Broadway production 
number Berlin had written for the 1924 edition of his Music Box Revue series, "Alice in Wonderland." Several others songwriters are also represented in the score, and Richman himself is credited as co-writer on two other songs that also became hits, the anthem-like "Singing a Vagabond Song” and the sensuous "There's Danger in Your Eyes, Cherie."

As the New York Times reviewer Mordaunt Hall pointed out, Puttin' on the Ritz combines "a fund of amusement," "singing that is captivating," and "the melody that lingers" indeed, the movie managed to establish four hit songs - however, those factors must work hard to counteract a storyline that is full of "banal episodes" (Hall 1930). After writing a love song together, Harry (Harry Richman) and Dolores (Joan Bennett) team up with two slightly older friends - Jimmy (James Gleason) and Goldie (Lilyan Tashman) - to perform a variety act. The quartet breaks up when the young sweethearts get a chance in a Broadway show. Success goes to Harry's head, however, and, preferring high society, he slights his old friends and argues with Dolores. When he goes blind from drinking bad bootleg alcohol, Jimmy helps take care of him. At the triumphant opening of her new starring show, Dolores reunites with the Harry. He comforts her about the loss of his vision: "I feel like I can see you for the first time."

Generically, Puttin' on the Ritz is primarily a melodrama, with the old-fashioned values of domestic melodrama transferred to the milieu of 1920 s show business. Family is the ideal state: the quartet of performers forms a surrogate family - loyal, frank, tolerant, caring, mutually supportive, honestly laboring. This has the strange consequence of making show business (so often characterized in other narratives, such as in Free and Easy, as base, superficial, and false) seem a safe haven of innocence, sincerity, and truth, while the rest of urban society is menacing, deceitful, and cruel. By contrast, innocence and purity of heart are present in this world as exemplified by this show business "family" and especially by the core 
of that family, the innocent, pure-of-heart, blonde, virginal heroine. ${ }^{1}$ The city is a place of temptation and danger. It causes the hero to wander from the path of virtue and thus to break away from the family. There are scenes of highly contrasting extremes of emotion (merry frivolity and righteous anger, tearful grief and ebullient joy). Further, the plot features other staple components of melodrama: fateful coincidences (a telegram from Jimmy and Goldie is neglected after being dropped on the floor); moralistic symbolism (Harry goes blind immediately after Dolores calls him “a blind fool”); improbable events (Harry, now blind, refuses to let Dolores know about his impairment - yet he readily reveals himself in the audience at her opening: onstage, she breaks down in tears while singing the love song they wrote together, and he stands up and concludes the rendition).

Nevertheless, the hero is not typical of naive melodrama. He has, in fact, something of the noble-but-flawed nature of many tragic protagonists: he has many admirable traits (enthusiasm, ambition, virility, tall height, lots of glossy black hair, and singing talent - within a musical, this last is a great, redeeming feature). But he also has a harmartia - his fatal flaw is a swelled head. His weakness is repeatedly emphasized by the dialogue and action; as Goldie says, "that guy needs a nine-day diet for his head." The faults that go with this - an egotism that leads to egoism, vanity, thoughtless flirtatiousness, attraction to social-climbing - send him to his downfall. He is partly responsible for his own fall from grace. This fact mitigates against the film having a purely melodramatic aesthetic. Yet, we cannot interpret Harry as a fully tragic hero. True, he seems almost monumental as he stands, spotlighted on a stage, pouring out

${ }^{1}$ Admittedly, Dolores is an innocent heroine befitting the urban show musical subgenre - she can trade wisecracks with the best of them, as she demonstrates in her very first scene.

CINEJ Cinema Journal: Tragicomedy, Melodrama, and Genre in Early Sound Films

Volume 5.2(2016) ｜ ISSN 2158-8724 (online) ｜ DOI 10.5195/cinej.2016.135 | http://cinej.pitt.edu 
"Singing a Vagabond Song." At other times, however, he is the legitimate butt of laughter of others. He is merrily teased by his friends for his unbounded ambitions - much as people want to tease for his boastfulness the hero of Beaumont and Fletcher's quintessential Jacobean tragicomedy of 1611, A King and No King. Drunk, he cavorts for his society friends, spouting baby talk. In these moments, he is very much a "mixed" character, and, as such, has a resemblance to tragicomic protagonists.

It is possible to say that the different characters in this story are inhabiting different generic worlds: Harry, the tragicomedic; Dolores, the melodramatic; Jimmy and Goldie, the comedic. This would be, however, an oversimplification. The characters and action of Ritz can be analyzed through the lens of Peter Brooks's view of the genres; he states that "the different kinds of drama have their corresponding sense deprivations" (Brooks 1976, 57). Brooks relates tragedy to vision and blindness, comedy to hearing versus miscommunication and deafness; and melodrama to "total articulation" and its loss in muteness - and, more generally, to "extreme physical conditions," of all sorts, that are used to "represent extreme moral and emotional conditions" (ibid, 56-7). ${ }^{2}$ Therefore, one can say Goldie's two scenes of pretending to be cheerful while holding back her tears have elements of both the tragicomic (in its mixture of smiling and crying) and the melodramatic (in its contrasts of extreme emotion and, more, as manifestations of not saying what one feels). On the other hand, Harry is irrevocably blinded -

${ }^{2}$ Brooks's correlation of genres and the senses is a conceptual framework, not a strict delimitation of these genres' semantic fields. Many melodramas of course do feature blindness, as one common kind of "extreme physical condition"; an example is the oft-filmed 1887 stage play Les Deux orphelines (The Two Orphans), by Adolphe d'Ennery and Eugène Cormon, and its famous D.W. Griffith-helmed 1921 movie version, Orphans of the Storm. 
this is another link to tragedy, invoking, as it does, Oedipus, an archetypal tragic protagonist. The film emphasizes that Harry loses sight but gains new insight - almost a spiritual vision; as Brooks says, blindness corresponds to the tragic drama, "since it is about insight and illumination" (Brooks 1976, 57). Despite the tragic element in Harry's disability, there is a strong sense that Harry's fall is fortunate. Unlike the heroes of Renaissance tragicomedy, there will be no miraculous physical cure for Harry, but there is a strong sense that he does achieve what Cope describes as "the metamorphosis of character ... transcendent rebirth" (Cope 1973, 265).

Today we are accustomed to sympathizing with heroes of far more unsavory natures than Harry, as portrayed in the film by Harry Richman. Nevertheless, we should not minimize the mixed reaction induced by the film's hero on audiences in 1929. Edwin Schallert of the Los Angeles Times demonstrated this in his review: "The picture does not make Richman a particularly sympathetic character": and, midway in the action, "any sympathy that the personality of Richman might have is destroyed by the blatancy of his character" (Schallert 1930). The film seems to have catered to a specialized taste - the sophisticated urban audience. Film historian Richard Barrios quotes the rave reviews from the New York press ("corking good," "no letdown," "all-around swellest," "sets a standard"), but reports further: "While receipts initially seemed to echo critical enthusiasm, the box office returns were ultimately a disappointment" (Barrios 1995, 215). Edwin Bradley offers a reason for the decline in profits as the picture moved from city to suburb to rural cinemas: "more countrified viewers, turned off by the star's abrasiveness, had no good word of mouth" (Bradley 1996, 223). The film did 
not earn money in non-urban areas. ${ }^{3}$ Earlier forms of tragicomedy, too, often "played" to a sophisticated educated or urban subculture. As Karl S. Guthke emphasizes, tragicomedy “does not appeal easily and immediately to the majority of readers and theatergoers" (Guthke 1966, $\mathrm{xi}, 136)$. The coterie nature of the audiences for this mixed genre is also implicit in much of Marvin T. Herrick's early history of the genre (Herrick 1962, 81, 91-92, 126, 170-1). Perhaps in the reception history of Puttin' on the Ritz, we have a slight indication that the film's success being limited to urbanites was analogous to the reception of tragicomedies during those earlier eras. To the wider audience, the hero's character was too unpleasant, too "mixed."

In Puttin' on the Ritz, the city is in many ways the alien place of danger of nineteenth-century American melodramatic cliché. Yet, here, melodrama takes on a tragicomedic tone: rather than being simply evil, the city is a place of role-playing, of false appearances. Early in the film, Harry wows a rough, working class audience with "Singing a Vagabond Song," which features a lyric that describes this attitude. In the middle section of the refrain, the stanza talks about a world of fashion, passion, the playing of parts, jewelry and "fool'ry." By contrast, the song's protagonist loves the road, God's heaven above, his song, and "the pal who will love me." Nevertheless, later on Harry ignores the wisdom of this lyric, which celebrates the simple life and close companions. He temporarily takes as his own the urban world of "fool'ry" and jewelry, where people are only playing a part. This is much like the worldview of Jacobean tragicomedy, in which we find an underlying cynicism about

${ }^{3}$ With exceptions, this statement might be generally true for all the early sad clown musicals, for it may not be a coincidence that profits for the sad clown musicals decreased as the rural, small town, and suburban cinema houses geared for sound. 
society and an emphasis on the artifice of social relations. Admittedly, Puttin' on the Ritz does not conclude with this view of human nature; it affirms the existence of genuineness and sincerity, as melodrama usually does. Nevertheless, it does at least refer to - and glance at - a more jaded, tragicomic view of the world.

In addition to its melodramatic heritage, Puttin' on the Ritz can also be seen as strongly rooted in comedic forms and utilizing comic techniques. The young lovers, the helpful friends, the obstacles and final romantic union, all are part of both comedic and melodramatic structures. The obstacles to the romantic union are mostly rooted in Harry's vanity; his hamartia thus also has characteristics of the internalized blocking force that has been increasingly popular in New Comedy structures since the time of Marivaux (Altman 1987, 1435).

The tone throughout much of the film is light, dependent on wisecracks, gags, and a sophisticated skeptical "knowingness." The style of the performers is often resilient, buoyant, casual, crisp, off-the-cuff, and nonchalant. Thus, despite its melodramatic shape and its leanings toward tragicomedy, the film still qualifies as a "musical comedy."

\section{Free and Easy}

Free and Easy was the first sound movie Buster Keaton made. Keaton is still hailed today for the comic masterpieces he produced throughout the silent film era, ending with The Cameraman (1928). The standard view, however, is that when Keaton went from independent production to being a cog in the mill at MGM studio, "his career as a filmmaker effectively ended" petering out with a series of "witless talking features," starting with Free and Easy (Cook 1996, 211). Indeed, critics noted at the time that the movie was "a mélange" of disparate 
elements, judging it "handicapped by a too-great abundance of extraneous material," first displaying "all the earmarks" of the musical revue format and then hovering "perilously close to emotional drama" (Strauss 1930; P.K.S. 1930). In this storyline, already conventional by 1930, a beauty contest winner, Elvira Plunkett (Anita Page), her mother (Trixie Friganza), and her manager, Elmer (Buster Keaton), travel from Gopher City, Kansas, to Hollywood in order to make Elvira a star. Elvira meets, argues with, and eventually romantically pairs with movie star Larry Mitchell, rejecting all ambitions for stardom. Meanwhile, Elmer, who is too bashful to declare his love for Elvira, goes through a series of misadventures. Nevertheless, his mishaps, along with Larry's assistance, lead to his attaining success as a screen comedian, cast opposite the domineering Mrs. Plunkett.

Free and Easy focuses on the comic misadventures of Buster Keaton as Elmer. It is pure comedy - just comedy, not musical comedy - throughout most of its running time. It is only halfway through the film that the musical elements appear - although, from that point on, they increasingly dominate the action. What skews the story away from the traditional New Comedy patterns of both non-musical and musical comedies is that the main protagonist does not attain his real desire - the girl. ${ }^{4}$ What he gets instead is success as a film comedian - an empty prize without love. As the movie review columnist for the Los Angeles Times opined, the movie has "a strange ending to a 'gag' comedy," for the plotline "does make a Pagliaccio"

${ }^{4}$ Keaton may seem too homely to be a leading man, but, born in 1895 , in 1930 he was only thirty-five years old, and his characters until then had "got the girl," for instance in his two previous starring vehicles, The Cameraman (1928) and Spite Marriage (1929). Nevertheless, Elmer's loss is somewhat generically predictable, for his rival, Larry Mitchell, is played by rising star, Robert Montgomery - born only six years after Keaton, but looking younger than his twenty-nine years. 
out of Keaton: "it is as the clown with the breaking heart that we leave him, with tears threatening the chalk of his make-up" (P.K.S. 1930). There are thoroughly melodramatic aspects to the denouement of Free and Easy - aspects dominated by what Brooks points out: melodrama's preoccupation with muteness, with not saying (Brooks 1976, 56). By emphasizing its hero's emotional innocence and his inability to speak his deeper emotions -first from bashfulness and then because of his comic profession - the movie takes on certain dynamics of the melodrama. Elmer's melodramatic lovelorn situation, however, is colored with tragicomic hues due to a number of elements.

The most tragicomic moment in the film is the final shot: Elmer participates in the musical finale of the film-within-the-film, in which he plays an aviator who is entrapped into marriage by an older, domineering queen of a make-believe Near East kingdom. Elmer's rival for Elvira, Larry, participates in this finale, as the sweetheart of a beautiful native girl, Minnie (Doris McMahon), whom the aviator has also fancied. So, on-camera, Larry gets the girl in the film-within-the-film; and, meanwhile, off-camera, Larry has also won Elvira. As Larry sings the love song to Minnie, he looks at Elvira, sitting on the sidelines watching, blowing kisses at him. Elmer, in heavy character make-up that closely resembles a traditional clown face, glances first at his "queen," then at Larry, then at Elvira, then up into space. (Figure 1.) Elmer then looks down, and two small black marks on his upper eyelids look like tears. This is a quintessential sad clown moment, one that captures the paradoxically blithe darkness of many early Hollywood musicals - a worldview that partakes of the tearful sacrifices of melodrama, but with a slightly cynical view of human affairs that spices these works with the flavor of tragicomedy. 
We must work backwards from this essential sad clown image, to other parts of the film that lead up to it and give it resonance. Immediately after telling Elmer of her engagement to Larry, Elvira emphasizes: "I'm just going to sit right here and watch your next scene, and you'd better make me laugh!" He proceeds to do so, despite his breaking heart. This is what Altman names as the central dilemma in these sad clown musicals: "the performer must sacrifice his own happiness in order to assure that of the audience, all the while covering his own misery in the clown's mask" (Altman 1987, 228). For the finale of Free and Easy, the audience is four-fold: Elvira; the diegetic film crew; the diegetic mass audience, for whom the film-in-the-film is intended; and us, the real mass audience. We become complicit in creating Elmer's tragedy: "you'd better make us laugh!"

Elmer's tragicomic dilemma occurs within a warped society, where make-believe dominates human behavior. Thus, Elvira, temporarily disillusioned with Larry, tells Elmer why she is not cut out for Hollywood: "To make it in movies you have to have a gift for pretending, and I just can't pretend. I could never be happy making believe all my life." Here, in Free and Easy as in Puffin' on the Ritz, there is a glancing reference to a worldview which sees society (or at least that part of society upon which the film dwells) as false artifice - a view reminiscent of Jacobean tragicomedy.

As part of this world of artifice, the film industry, with its surreal coexistence of fantasy and reality, increasingly dominates the second half of the film. We travel with Elmer through five different film sets (and eight behind-the-set spaces), as he stumbles into and through them. Finally, on the two sets for his own movie, Elmer becomes fully part of this world of make-believe. The world of movie-making becomes Elmer's universe. It is, indeed, a frightening universe in which he is trapped, one in which he finds himself making love to a 
homely, bullying woman old enough to be his mother - a particularly nightmarish version of the Oedipal situation described by Freud. ${ }^{5}$

Elmer's involvement in this world of artifice leads to his tragicomic dilemma. The tone of his story shifts from comedy to tragicomedy, starting with the image of his glum face being plastered with clown-like make-up: white powder; hair heavily greased down, one curl falling over the forehead; thin black eyebrows, bowed as if in constant worry; small dots in the center of his upper eyelids; lips, a dark slash across the face. The make-up man is aggressive and unfeeling in wielding his powder: under the onslaught, Elmer can only gasp for breath like a newborn baby. Ironically, just as Larry maneuvers to reconcile himself with Elvira, Elmer is caked in a comic mask. Although brief, this powerful image begins to shift the tone of the film, warning us that Elmer may not end "happily ever after."

To summarize my interpretation of Puttin' on the Ritz and Free and Easy up to this point: both tend towards the tragicomedic. In both, at times, society is seen as dominated by artificial role-playing (even though both reaffirm a belief in innocence and sincerity). This mirrors their overall concern with the relationship between real life and performing, offstage and onstage. Ritz features a tragicomic hero - one who draws a complex, mixed response from the audience and whose fortunate fall has tragic undertones. Free and Easy complicates its simple comic patterns by leading the hero to a place of tragic isolation from the society of value (that surrounding the beautiful, innocent, virginal blonde heroine) and traps him in a society dominated by "pretending" and "making believe" - the filmmaking industry. Their

5 The actress playing Mrs. Plunkett, Trixie Friganza, was born in 1871, and thus was twentyfive years older than Keaton-indeed, old enough to be mother to Keaton (or to Elmer).

CINEJ Cinema Journal: Tragicomedy, Melodrama, and Genre in Early Sound Films

Volume 5.2(2016) | ISSN 2158-8724 (online) | DOI 10.5195/cinej.2016.135 | http://cinej.pitt.edu 
endings are notable for being more downbeat than those in other sad clown musicals of the time. ${ }^{6}$ Compared with others of their type, the two films have a strong philosophical bent, however heavy-handed, superficial or stereotypical they may be in exploring these more thoughtful undertones. ${ }^{7}$

\section{Odes to the Grotesque}

The stories-within-the-stories of both Puttin' on the Ritz and Free and Easy feature commoners who invade royal courts and are crowned, as are commoners in venerable tragicomedies such as $A$ King and No King. (Figures 2 and 3) The genre of tragicomedy acts as a bridge from the world of heroic tragedy to the land of peasant or bourgeois comedy, and such cross-class characters within tragicomedies embody that same fusion of dichotomies. In these two movies, this transgression occurs vividly in the fictional settings of performance - and those migrations offer vague parallels to the ways in which Harry tries to break into Manhattan high society in Ritz and the Plunkett family tries to break into the world of Hollywood film royalty in Free and Easy.

\footnotetext{
${ }^{6}$ For instance: The Jazz Singer and Lucky Boy are reconciled with their parents; the protagonists of Mother's Boy and Mammy are cleared of crimes; those of Melody Lane, Say It with Songs, and Honky Tonk are reunited with their children; and the heroines of Broadway Melody, My Man, and Hello Everybody successfully bury their heartbreak by pursuing their careers.

${ }^{7}$ From this same era, Blondie of the Follies (1931) is a semi-musical (it has two and a half musical numbers) with another sad clown narrative that develops some remarkably philosophical tragicomic tonalities (and utilizes tragicomedic elements) before finding its melodramatic happy ending.
} 


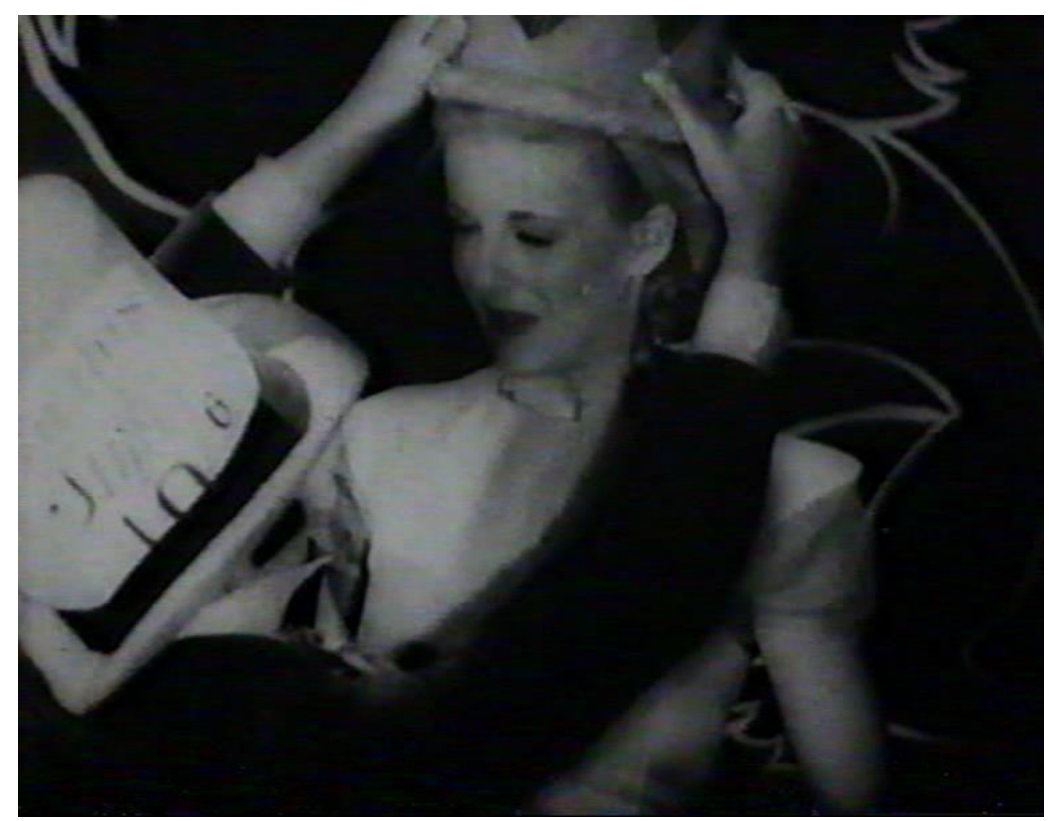

Figure 2. In the play-in-the-film of Puttin' on the Ritz (Edward H. Sloman, 1930), Dolores (Joan Bennett) is crowned as "Alice in Wonderland."

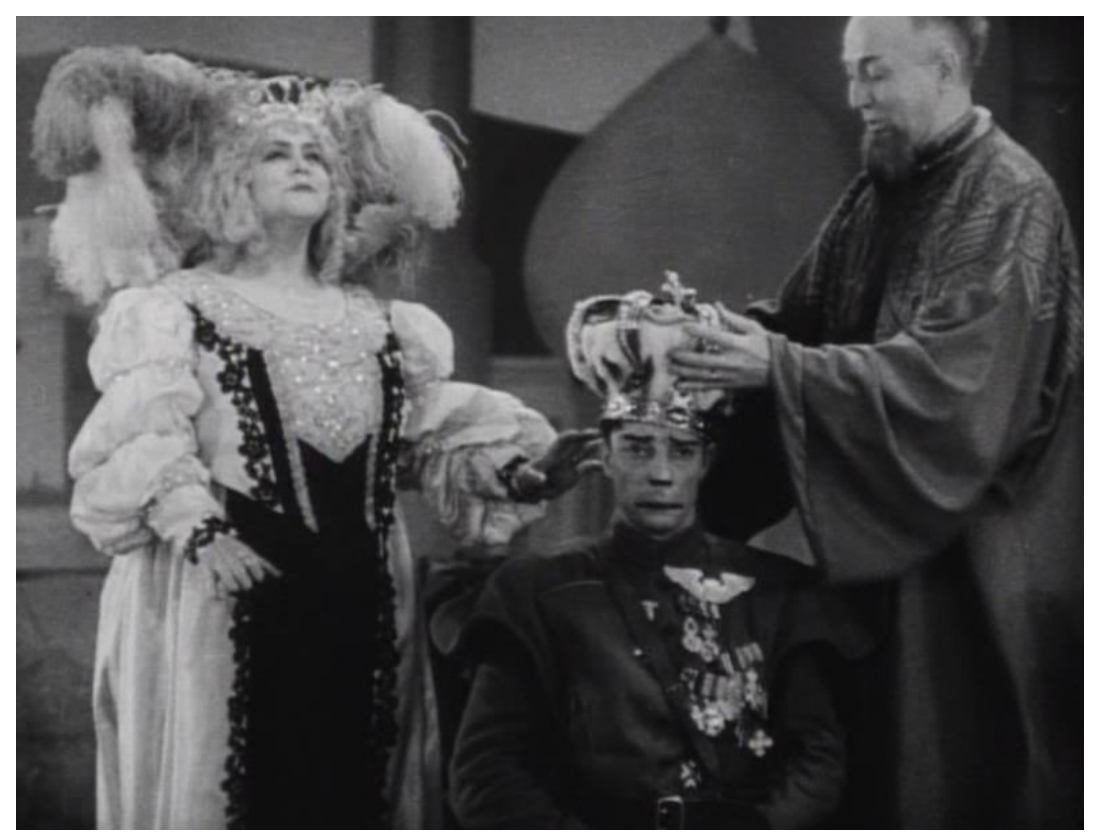

Figure 3. In the film-in-the-film of Free and Easy, Elmer is crowned king of a mythical land. 
The musical production numbers within Puttin' on the Ritz and Free and Easy lead us to supernatural events and images, linking the films even more strongly to the metaphysical concerns of tragicomedy - an aspect of the genre that overlaps with the grotesque. As Kayser writes, beginning with Friedrich Schlegel's proto-Romanticism, "the grotesque now opens the view into a chaos that is both horrible and ridiculous. A new word, tragicomedy, is thus made to adjoin the grotesque"; indeed, "tragicomedy and the grotesque are conceptually linked" (Kayser, 53, 54). ${ }^{8}$

In the title number of Puttin' on the Ritz, performed in the middle of the movie during the triumphant opening night of a Broadway revue, Harry sings the introductory verse in front of a drop curtain with a distorted, arching skyscraper. ${ }^{9}$ (Figure 4.) As he launches into the chorus of the song, the curtain lifts. It reveals a cityscape even more disturbing than the first: canted lampposts and towering, leaning skyscrapers of blackness, with eyes and teeth made of irregularly-shaped lighted windows and, most odd of all, arms and hands reaching into the night sky. We barely get a glimpse of the complete picture, however, before the camera framing focuses our attention, during four complete refrains of the song, first to Harry and then to both white and black dancing choruses.

\footnotetext{
${ }^{8}$ Guthke disagrees somewhat with Kayser and distinguishes decidedly between tragicomedy and the "nightmarish world of the grotesque and the absurd," but he also acknowledges that their tonalities overlap (Guthke 1966, 75, 61).

${ }^{9}$ Later on in Puttin' on the Ritz, Richman also reprises "Puttin' on the Ritz" in a much simpler nightclub setting.
} 


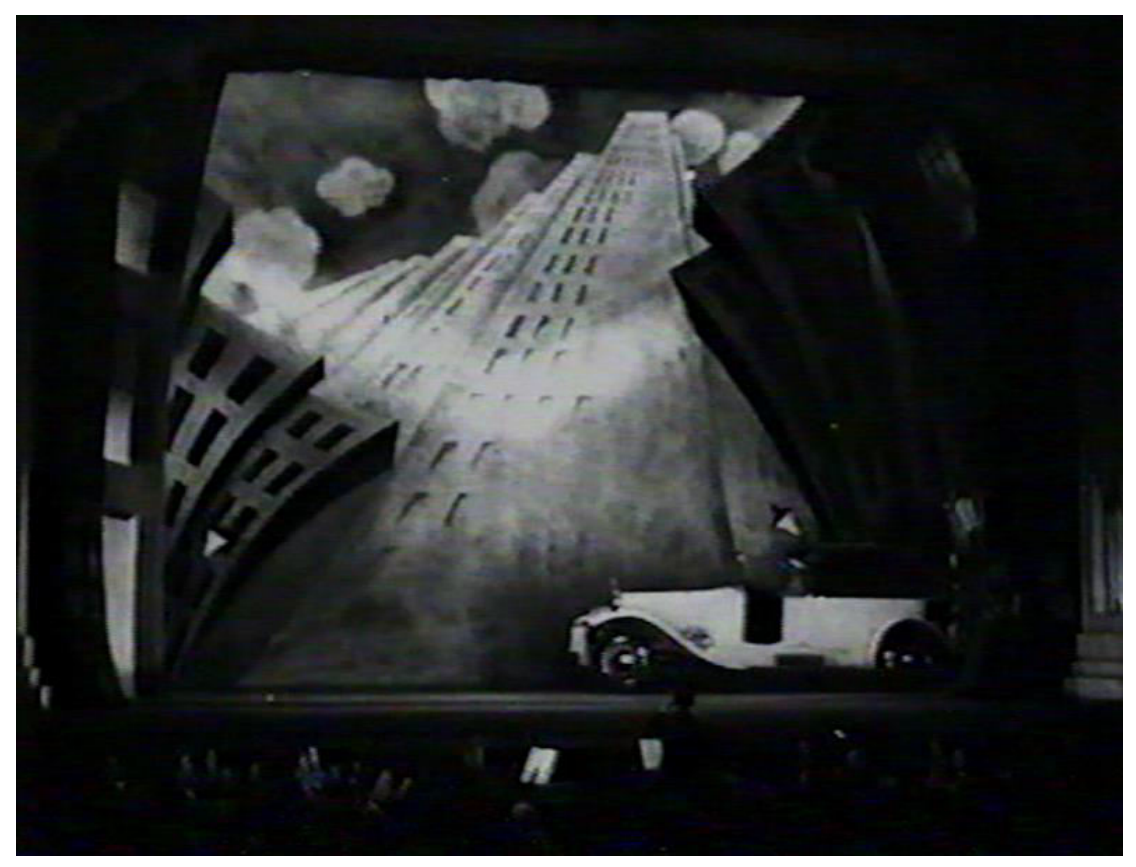

Figure 4. A skyscraper dominates the expressionistic urban nightworld at the beginning of the "Puttin' on the Ritz" staging.

During the fifth, final refrain, however, the image shifts to a longer shot, allowing us to take it all in. As Harry and all the dancers fill the set - on both upper and lower levels the menacing buildings, too, begin to dance. The face on a billboard (which inanely advises to "Chew Chewy Gooey Gum") also becomes alive: its eyes roll madly in opposite directions as its lips move, mouthing silently like an insane person. (Figure 5.) 


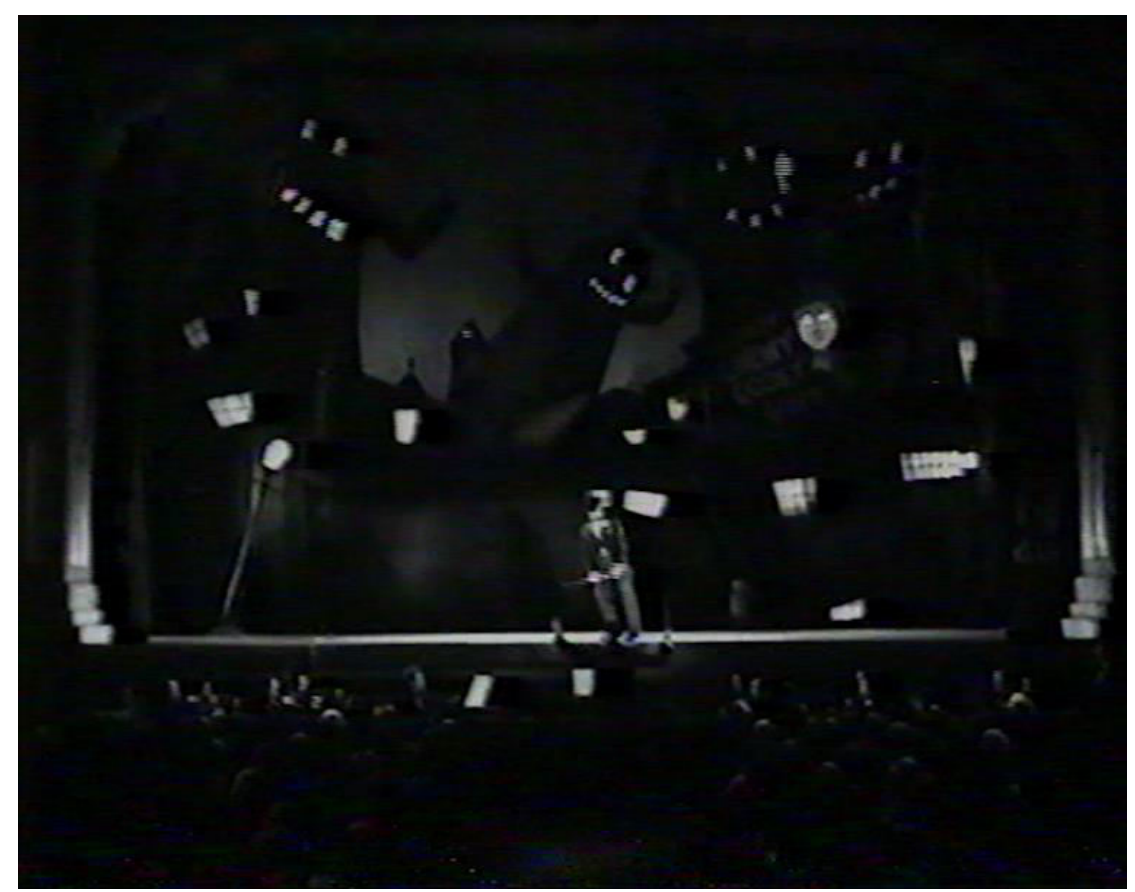

Figure 5. "Puttin' on the Ritz" reaches its climax as the leering anthropomorphic buildings start to dance.

The grotesque imagery feels absolutely right, although this Halloween view of the urban landscape finds no origins in the song's lyric; if anything, it relates to the brooding restlessness of the song's melody, with its cross-rhythms and unexpected flatted sixth just before the title phrase. The reviewers of the time noted the exceptional designs by William Cameron Menzies and the audience response to them - as Variety put it, the "crazy landscape that becomes animated," was "an applause inducer" (Variety 1930). This is a remarkable production number, and contemplating it brings up again the issue of the film's ambiguous attitude towards the city. 
In his lyric for "Puttin' on the Ritz," Irving Berlin celebrates the spectacle of poor blacks dressing up and parading in their gaudy finery during their night off. ${ }^{10}$ Like them, Harry, too, is a working-class man who puts on airs, and his pretensions are as laughable as theirs. In this aspect, he is the alazon of New Comedy - the braggart, the poseur, Plato's man who, not knowing himself, thinks himself better than he is.

Yet, there are other, more positive, aspects to the city and Harry's role in it. The city is also the place where we, the spectators, are entertained. In the production number built around the title song, "Puttin' on the Ritz," the blacks, when they appear, are not objects of ridicule; their dance is full of life, vitality and aesthetic interest - as is Berlin's song, which has drive and sophistication in both rhythm and rhyme. Here, celebrating the urban landscape, Harry is masterful and compelling, and it is here that the film is most alive, most vibrant, most at home, most convincing. This film loves the city - while presenting it, too, as macabre and ominous. Tragicomedies are renowned for their empty landscapes, not fitting the conventional settings of the royal court of tragedy, the idealized countryside of the pastorale, or the bourgeois interior of comedy and domestic melodrama. The enchanted island of Shakespeare's The Tempest, the rocky mountain ledge in Calderon's Life Is a Dream, the dream landscape of Felicja Kruszewska's The Dream, the crossroads of Samuel Beckett's Waiting for Godot - all represent an unstable place decidedly not of civilization. These indeterminate spaces might symbolize the identity crisis of the tragicomic protagonist, described by Guthke as "the loss of

${ }^{10}$ Audiences in the twenty-first century are more familiar with a second set of lyrics that Irving Berlin wrote for "Puttin' on the Ritz" during 1946, when mockery of African Americans was no longer politically correct, especially after the morale boosting era of World War Two. Berlin shifted from a focus on observing working-class blacks to that of ogling rich elites.

CINEJ Cinema Journal: Tragicomedy, Melodrama, and Genre in Early Sound Films

Volume 5.2(2016) ｜ＩSSN 2158-8724 (online) ｜ DOI 10.5195/cinej.2016.135 | http://cinej.pitt.edu 
the 'self," inherent in modern life (Guthke 1966, 111). These liminal spaces also operate as a meta-symbol of the liminal space that tragicomedy occupies between the comic and tragic genres.

The other production number in Puttin' on the Ritz is as ambiguous as the staging of the title song. It features Dolores as the eponymous heroine of the song "Alice in Wonderland." At this point in the film, the image originally turned to color; unfortunately, only black and white prints circulate today. Lacking the original, vivid, surreal quality of its early Technicolor, the number leaves much to be desired. While Lewis Carroll's dreamlands were disorienting and disconcerting, evoking in the reader some of the fascination of the grotesque, the dreamland in Puttin' on the Ritz is benevolent and cute. Carroll's Alice reacts to her adventures with a refreshing lack of sentimentality; she is, rather, resigned, angry, stubborn, or irritated. Dolores' Alice is, quite simply, delighted, following the indications of Berlin's lyric: "Come along with Alice ... to the pretty palace, where they're all so grand."

Nevertheless, some of Carroll's surreal imagery survives: in the anthropomorphic animals - the frenetic, ever-grinning Cheshire Cat; the combative Rabbit and Lion; the giant, oysters (who are both weeping and dancing - yet another tragicomic mixture); and chorus women dressed as chess pieces and playing cards. The most striking images in the number, however, come near the beginning: the gigantic looking glass, filled with trans-illuminated, billowing mists; Alice and her mirror image greeting each other; Alice, poised on the edge, beckoning us to follow her; and then the first setting found through the glass - a checkerboard with jumping chess pieces and Alice frolicking in this odd "nowhere" - a limbo space. (Figure 6.) This image then transforms into the most striking of the number: the checkerboard world 
compressed and distorted as in a fun-house mirror, as the chess pieces and Alice jump back and back, away from our vision, and blur into nothing. (Figure 7.)

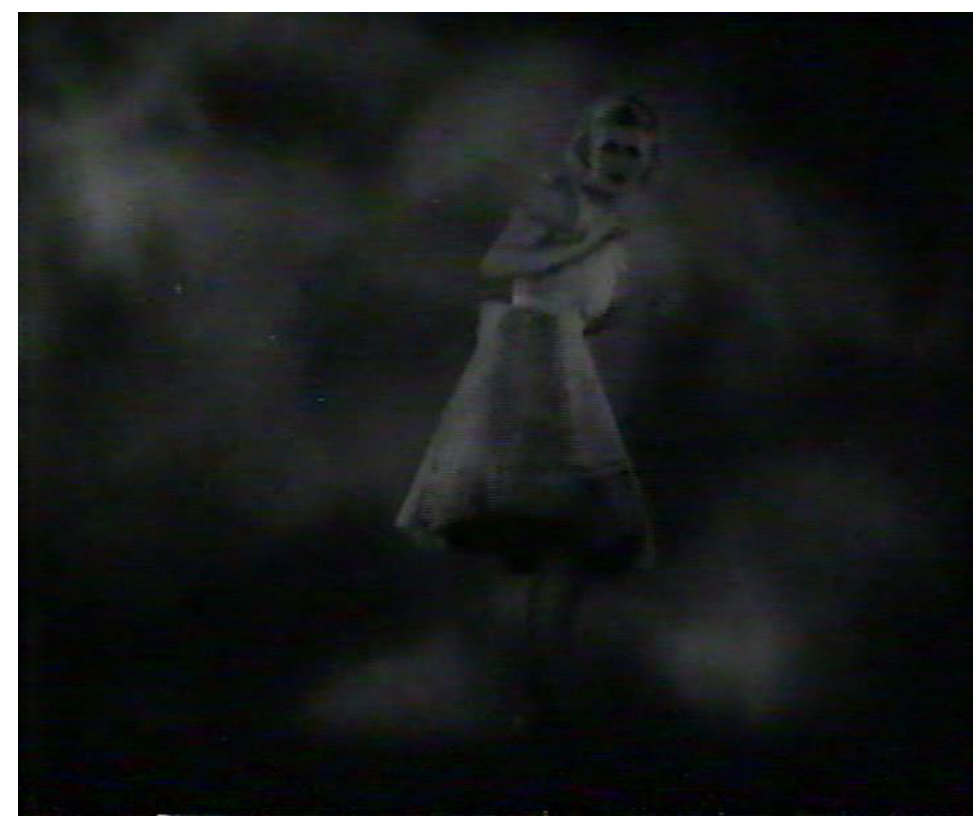

Figure 6. In Puttin' on the Ritz, the liminal space of tragicomedy: Alice on the edge between two worlds in "Alice in Wonderland."

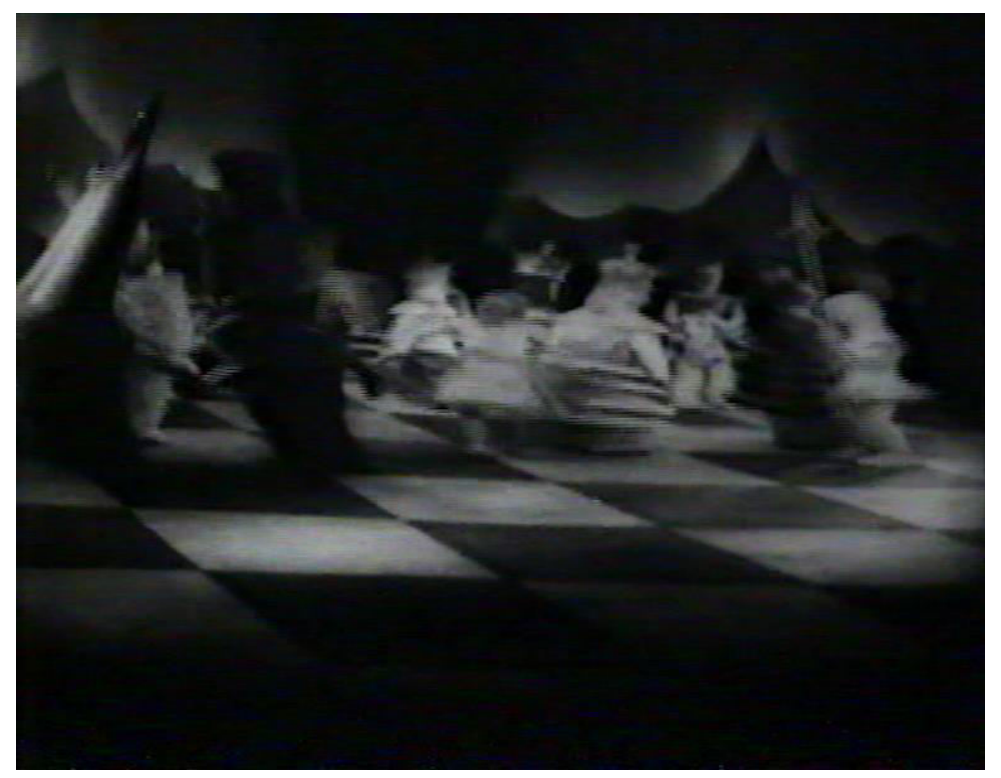

Figure 7. In Puttin' on the Ritz, Alice, through the looking glass, in a distorted world. 
Once we reach the next setting, a throne room, however, this production number begins to sink. Only a brief, virtuosic dance by the Mad Hatter relieves the sense of stilted anticlimax. Dolores displays no musical comedy performing ability, she sings not (the song is performed by an unseen tenor) and dances not (beyond a few runs and skips). Nevertheless, the close-ups of Joan Bennett are beautiful, if repetitive, and must have looked even more gorgeous in the early Technicolor of these last ten minutes of the movie. Too, in color, the heightened surreal quality of the costumes and sets must have been accentuated strongly, lending them a fascination of their own. At the number's end, Alice is crowned queen (Figure 2); then the image dissolves, and we see her back in her rocking chair, asleep.

In context, the number gains greater irony. Harry has come to witness Dolores' success, but she is silent throughout; sightless, he can only imagine her performance amidst this intensely visual spectacle. Further, it is only at this point, when the hero is blind, that the world erupts into color, taking us to a new dimension of visual experience. Perhaps Harry's new, more spiritual insight finds its manifestation in this new dimension - both the dream dimension beyond the looking glass and the new dimension of color. In this interpretation, the color symbolizes Harry’s improved inner, spiritual vision.

The "Alice in Wonderland" number acts as a contrast to "Puffin' on the Ritz." Musically, "Ritz" features complex rhythms and lush harmonies; "Alice" is a dainty and pure melody. "Ritz" is America - New York streets; "Alice" is Old World - courtiers and thrones. "Ritz" is urban and urbane; "Alice" has hints of the bucolic. Yet both feature the characteristic lyrical trait of their songwriter, Irving Berlin, which can be summarized as "come along" (Hamm 1997, 102-3; Garber 2006, 151-61). In "Ritz," the singer encourages the listener "why don't you go ... come with me." In "Alice," the invitation is "Come along with Alice ... come 
along, let's pass through." As early as his 1911 hit, "Alexander's Ragtime Band," Berlin's "come along" gesture always cues the listeners to recognize that they are being invited to participate in the world of show business entertainment. Both Lenox Avenue and Wonderland are, for Berlin, places of show business spectacle.

Berlin's lyrics for "Alice in Wonderland" exemplify what Feuer calls the "Ode to Entertainment": "The narratives of musicals place themselves firmly within a long tradition of popular entertainment ... The Ode to Entertainment is working out of this shared tradition" (Feuer 1993, 36). Further, "wherever such numbers occur, they always serve a finale function, including us in the celebration of another entertainment triumph" (ibid, 37). This "showbiz" mode links itself most closely with the comic mythos. In musicals with a New Comedy structure, the Ode to Entertainment is part of the celebration of the united romantic couple, who are a metaphor for the triumph of spring. As Northrop Frye describes, these celebrations become an expression of the communitas of a community of goodwill (Frye 1957, 43-48, 16386). At the story's end, all negative elements are either integrated into this society or expelled and the "good" society takes form around the couple.

Because musical comedy numbers that glorify entertainment were utilized by members of the mass audience for their own dancing and amateur music-making, the songs carried the sense of mythic comic celebration into everyday life. When the celebration includes dark elements in the composition of a song (as in the darkly brooding melody of "Puttin on to Ritz") or within the presentation of a song (as with the surreal staging of the number), it may complicate an audience member's relationship to his or her own daily dancing, singing and music-playing. Thus, these songs can carry tonalities of melodrama, tragedy, or tragicomedy into the everyday lives of individuals in the audience and, therefore, into society.

CINEJ Cinema Journal: Tragicomedy, Melodrama, and Genre in Early Sound Films

Volume 5.2(2016) ｜ＩSSN 2158-8724 (online) ｜ DOI 10.5195/cinej.2016.135 | http://cinej.pitt.edu 
In both production numbers in Puttin' on the Ritz, the Ode to Entertainment invites the audience to enter a world where inanimate objects come alive, a world which draws on grotesque imagery. As Kayser summarizes:

The grotesque is the estranged world ... the elements in it which are familiar and natural to us ... suddenly turn out to be strange and ominous. ... the categories which apply to our world view become inapplicable. ... the fusion of realms which we know to be separated ... the loss of identity, the distortion of "natural" size and shape, the suspension of the category of objects, the destruction of personality ....

We are unable to orient ourselves in the alienated world, because it is absurd. ... The grotesque ... is primarily the expression of our failure to orient ourselves in the physical universe. (Kayser 1963, 184-185)

In Puttin' on the Ritz, grotesqueries fill the production numbers (darkened, dancing, leering skyscrapers; mirror-doubles; distorted looking glass chess boards; dancing, weeping oysters; Mad Hatters), tying in with the tragicomic tonalities of the plot. Rather than inviting us to a cheerful "Singin' in the Rain" or affirming "That's Entertainment," Puttin' on the Ritz beckons us into worlds of the macabre and distorted. ${ }^{11}$

\footnotetext{
${ }^{11}$ Admittedly, "Alice in Wonderland" partakes of another aesthetic as well, which Kayser distinguishes from the grotesque - that of the fairy tale. There, the extraordinary is part of the natural condition of the world, so there is no disorientation effect arising from its surreal elements. That is why Alice, here, is merely delighted with her dream-world, not disconcerted. However, Kayser does tell us that, in one aspect of the Romantic grotesque "dreams ... [are] used to define the source of creativity" (Kayser 1963, 184). Here, in "Alice," the dream-world corresponds both to the overflowing bounty of show business creativity and to Harry's newfound insight — a conflux of associations that may relate to Romanticism's conflation of dream, the grotesque, and creativity.
} 
Although it does not partake of the grotesque, it is appropriate here to touch again on Harry's anthem, "Singing a Vagabond Song," which, the above discussion makes clear, is also an Ode to Entertainment: a celebration of the life of song. It, too, is used in a manner that links it with the tragicomedic. After Harry has quarreled with Dolores, his wealthy false-friends lead him, drunken and petulant, to the piano and get him to sing this song. He stops (on the line, "where is the pal, one who will love me"). He walks away, saying, "No, I don't want to sing." The serious drama of this interruption is deflated by his next line: "Maybe after a while." Harry cannot completely relinquish a chance to show off; and it is Richman's canny delivery of the line that lends it this nuance - his understated, spontaneous-seeming delivery skillfully brings the comic into this serious moment. This scene provides a good example of how this film - and this type of film - tempers its melodramatic structures with comic tonalities and colors its comedic musical celebrations with tragicomic dynamics.

In Free and Easy, also, there are two musical numbers that include inexplicable events and supernatural elements. The first ("Oh, King! Oh, Queen!”) is the more straightforwardly comic. It has several sections, and the sequence concludes with Mrs. Plunkett (as the Queen) and Elmer (as the aviator) stripping down to their underwear to perform a parody of lyric ballet; the coup de grace of this satirical number has the aviator climbing up to a balcony to jump (like an acrobat) down into the Queen's arms. Instead, he dives into the pool beside her and disappears into its depths - only, as she proves the next second, it is actually only ankle-deep, leaving the Queen alone and perplexed. (Figures 8 and 9.) 

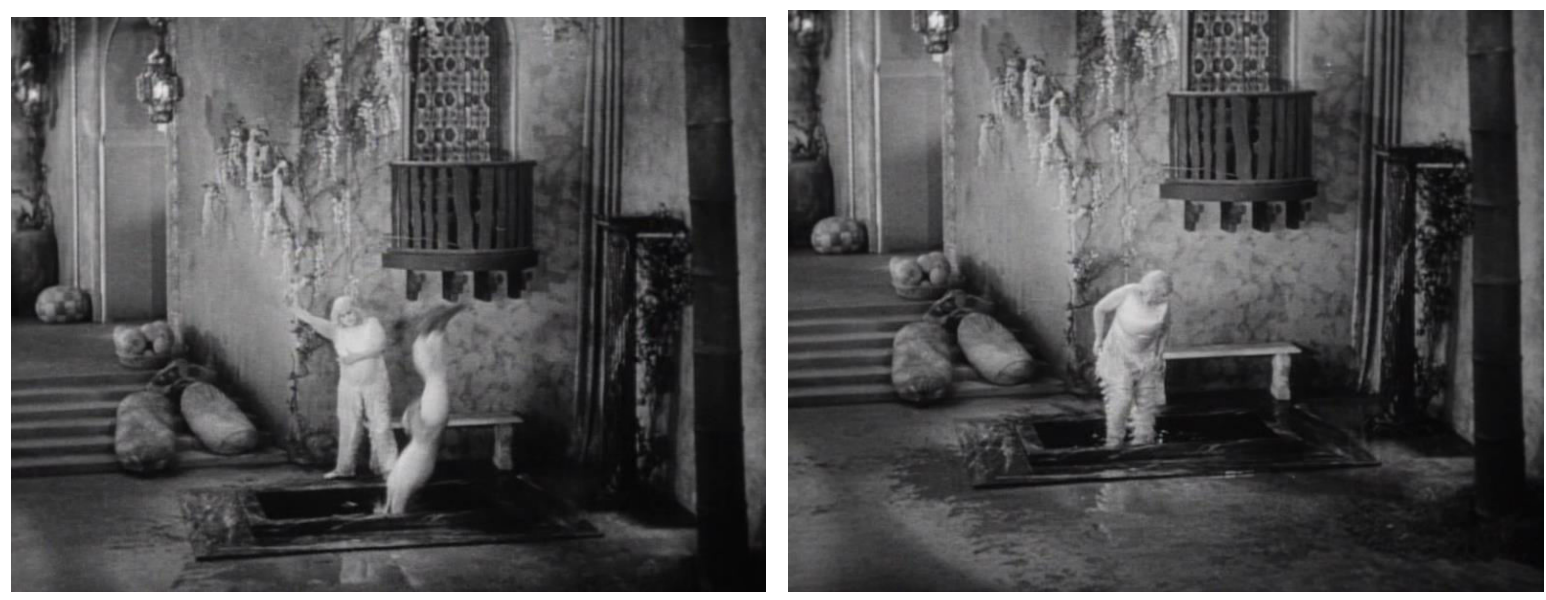

Figures 8 and 9. For the movie-in-the-movie of Free and Easy, Elmer mysteriously dives and disappears into an ankle-deep pool, leaving the Queen mystified.

The aviator's unexplained ability to perform magical vanishing acts is expanded upon in the next musical number. Again, this sequence has several sections: the Elmer-aviator character wheels his airplane into a desert waste (with outcropping rocks on either side, a couple of ruined buildings, and sand dunes reaching out to the horizon). (Figure 10.) There, he teaches Minnie and a throng of natives "The Free and Easy." This is another example of the Ode to Entertainment. This time the lyric exhorts us to "Follow me and dance ... The Free and Easy ... let yourself relax." Once again, as in "Alice in Wonderland," we find a musical number that glorifies the culture of show business entertainment combined with a setting that is akin to the "nowhere" limbos of tragicomedy. 


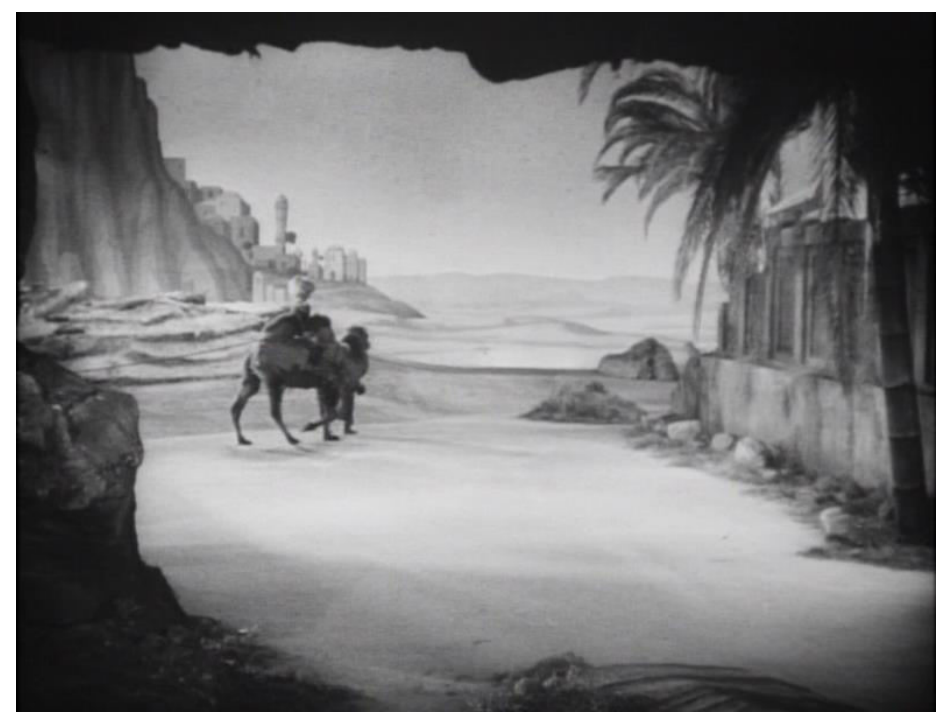

Figure 10. During Free and Easy's movie-in-the-movie, Elmer leads his camel, which in turn pulls his airplane, into the desert wilderness: a liminal tragicomedic space appropriate for the appearance of the sad clown.

The number soon becomes even more tragicomedic - and more surreal. Once Elmer has led a chorus of "The Free and Easy," he dances backwards and falls into a huge box, which has appeared out of nowhere. Therein he stays, as Minnie performs her own song and dance choruses of "The Free and Easy." Then, the box lid flies open, and the aviator emerges dressed as the traditional baggy-pants circus clown based on Pierrot: a white, balloon-like costume, with ragged patches on it; three huge, fluffy buttons down the center front; neck ruff and wrist ruffs; and conical cap. He is attached to four strings that lead up to the sky; he is both Jack-in-the-box and Jumping Jack. (Figure 11.) Supported by these strings, he performs a floppy dance - leaping from side to side, flopping onto his behind - weightless and graceful, yet formless and clumsy. The strings loosen, and he collapses in a heap on the ground; then 
they pull taut, and he is pulled up to vanish into heaven above. ${ }^{12}$ The sequence continues, with the arrival of the Queen and then with Elmer-aviator's reappearance, disguised now as a soldier in cloak, helmet and moustache.

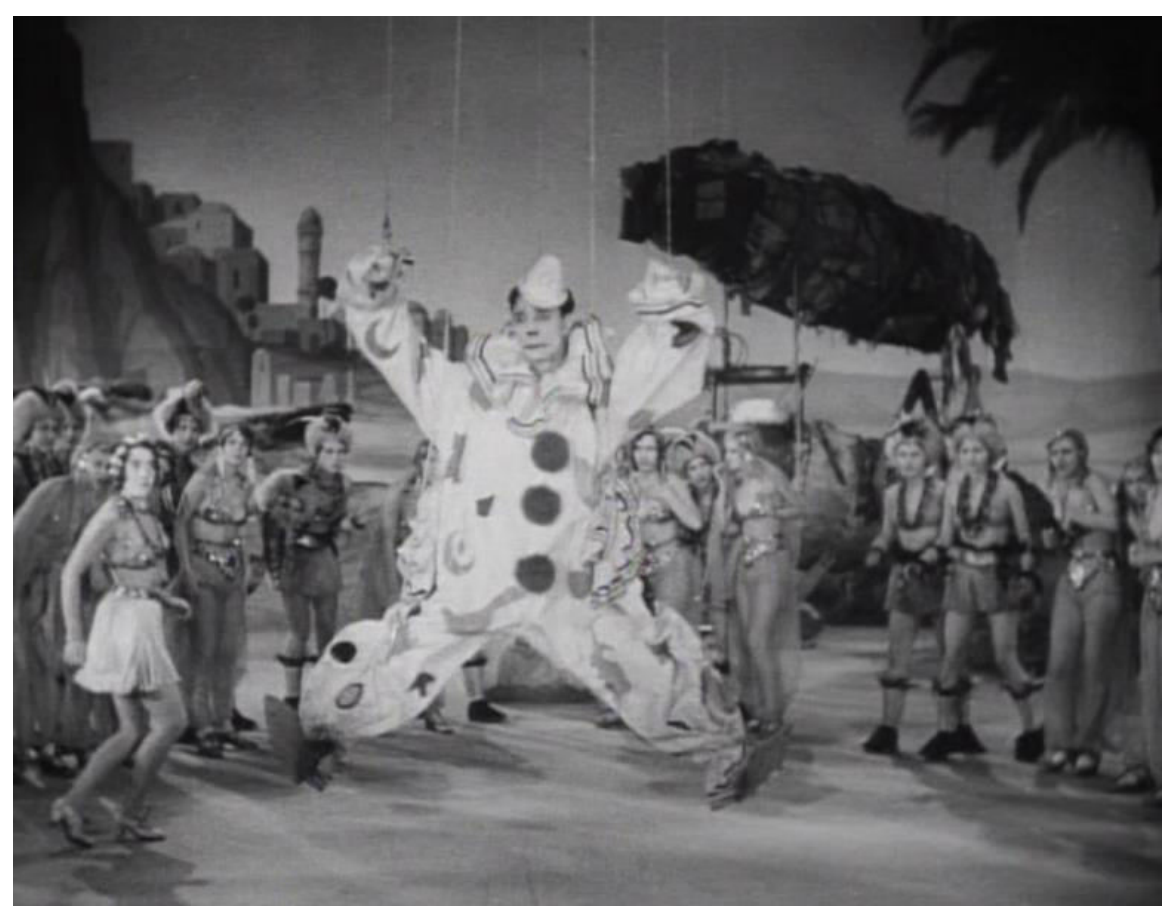

Figure 11. In the desert setting of "The Free and Easy" musical number, Elmer, as a magic clown, inexplicably emerges as a jack-in-the-box, transformed into a life-size marionette.

In Free and Easy, the film-within-the-film is extravagant, exaggerated, and fanciful throughout. Amidst its odd juxtapositions and incongruities, this clown-marionette dance is the

${ }^{12}$ At this point, there is a cut to a longer shot, which shows a frame at the top of the screen, as if the camera were within a large cave opening - a similar framing to that seen in Figure 10. This creates a proscenium effect, which enables the clown figure to vanish out of sight without its being too jarring. 
oddest element of all - striking, surreal, supernatural. Elmer's earlier mysterious vanishing into the shallow pool could be accepted as generically conventional, coming as the punchline at the end of a comic sequence. But the Jumping Jack dance exceeds the bounds of convention, and it has a different resonance because it is slightly unusual in the genre. ${ }^{13}$ It creates a close identification of Elmer with the archetype of the clown. This striking Jumping Jack dance invites comparison with Felicja Kruszewska's use of the Jumping Jack in her 1927 play The Dream. In Kruszewska's nightmare vision of a twisted society, the Green Jumping-Jack Who Should Be Hanging on the Lamp is, in the words of the Girl Who Is Dreaming, "the embodiment of all that is most nonsensical" - the symbol of a world where there is no sense to existence (Kruszewska 2002, 72). In Free and Easy, Elmer is trapped as part of a world of "nonsense" which loses its meaning with the loss of innocent romantic love. It is all the more powerful for occurring in the middle of this sequence; it comes from nowhere and leads nowhere - except, of course, it leads our expectations toward Elmer's tragicomic denouement. Thus, various odd tonalities prepare the way for Elmer's ultimate, tragicomic fate: in the glare of the spotlight, in the midst of a Freudian Oedipal nightmare, lovelorn, he makes others laugh. He becomes the archetypal sad clown. It is while he is emotionally suspended in this dilemma that we leave him, and the screen fades to black. The End.

\footnotetext{
13 It is possible; however, that, at the time, Elmer's dance was not as unusual as it seems today. The stage star Fred Stone, in musicals on Broadway in the 1910s and 1920s such as Criss Cross (1926), performed acrobatic comedy in fairy tale settings amidst plots with a sense of free association and loose narrative structure, similar in some ways to the movie-in-the-movie of Free and Easy, but without the tragicomic tonalities.
} 


\section{Conclusion}

Both Puttin' on the Ritz and Free and Easy imbue their Odes to Entertainment with inexplicable, strange, magical, or macabre images. This invitation to the grotesque corresponds to a vision of the world as "fool'ry" and "pretending." It is a world where innocence and purity still exist and, in their own way, triumph. Nevertheless, that triumph can only be partial in a world gone slightly sour. As part of this, both films end without a full resolution of their tensions.

If, with Eric Bentley, we can say there are two types of tragicomedies, in the broadest outline, these two films represent the options (Bentley 1967, 318-9). Puttin' on the Ritz might be viewed as a tragedy with a happy ending. Free and Easy can be interpreted as a comedy - as the Los Angeles Times reviewer put it, a "gag" comedy - with a sad ending. Indeed, perhaps it even features a tragic ending, in that Elmer moves in the direction of isolation from the society that matters - that surrounding the pure and beautiful blonde heroine. ${ }^{14}$ Nevertheless, an analysis would be strained that sought unconditionally to place Puttin' on the Ritz and Free and Easy within the tragicomedy genre - overall, Puttin' on the Ritz is a melodrama and Free and Easy comedy - but both movies intriguingly play with tragicomic modalities and tragicomedic structures. These musicals may seem like simple and superficial entertainments. Nevertheless, an examination of the interplay of genres within them - their mixtures of comedy, melodrama, and tragicomedy - reveals a greater complexity in

\footnotetext{
${ }^{14}$ More precisely, Free and Easy has a "double" ending, with deserved happiness for the comic couple and undeserved misery for the tragicomic clown.
} 
their makeup. The analyst becomes like Elmer in his film-within-the-film, diving into what seems like a shallow pool, only to disappear into unexpectedly profound depths

\section{BIBLIOGRAPHY}

Altman, Rick. 1987. The American Film Musical. Bloomington: Indiana University Press.

Barrios, Richard. 1995. A Song in the Dark: The Birth of the Musical Film. New York: Oxford University Press.

Bentley, Eric. 1967. The Life of the Drama. New York: Atheneum.

Bradley, Edwin M. 1996. The First Hollywood Musicals: A Critical Filmography of 171 Features, 1927 through 1932. Jefferson: McFarland.

Brooks, Peter. 1976. The Melodramatic Imagination: Balzac, Henry James, Melodrama, and the Mode of Excess. New Haven: Yale University Press.

Cook, David A. 1996. A History of Narrative Film, third ed. London: W.W. Norton.

Cope, Jackson I. 1973. The Theater and the Dream: From Metaphor to Form in Renaissance Drama. Baltimore: John Hopkins University Press.

Feuer, Jane. 1993. The Hollywood Musical, second edition. Bloomington: Indiana University Press.

Frye, Northrop. 1957. Anatomy of Criticism: Four Essays. Princeton: Princeton University Press.

Guthke, Karl S. 1966. Modern Tragicomedy: An Investigation into the Nature of the Genre. New York: Random House.

Hall, Mordaunt. 1930. "Melody and Beauty,” New York Times Feb. 15, 15.

Hamm, Charles. 1997. Irving Berlin: Songs from the Melting Pot-The Formative Years, 19071914. New York: Oxford University Press.

CINEJ Cinema Journal: Tragicomedy, Melodrama, and Genre in Early Sound Films

Volume 5.2(2016) | ISSN 2158-8724 (online) | DOI 10.5195/cinej.2016.135 | http://cinej.pitt.edu 
Henke, Robert. 1997. Pastoral Transformations: Italian Tragicomedy and Shakespeare's Late Plays. Mississauga: Associated University Presses.

Herrick, Marvin T. 1962. Tragicomedy: Its Origin and Development in Italy, France, and England. Urbana: University of Illinois Press.

Kayser, Wolfgang. 1963. The Grotesque in Art and Literature, trans. Ulrich Weisstein. Bloomington: Indiana University Press. Originally published as Das Groteske: seine Gestaltung in Malerei und Dichtung (Oldenburg: Gerhard Stalling Verlag, 1957).

Kruszewska, Felicja. 2002. A Dream, trans. Jadwiga Kosicka. London: Routledge.

P.K.S. 1930. "Slapstick of Keaton in Sound,“ Los Angeles Times, Apr. 12, A7.

Strauss, H. David. 1930. "Free and Easy," Billboard, Apr. 26, 22.

Variety, 1930. “Puttin' on the Ritz." Review. Feb. 19, 21.

Wolf, Stacey. 2002. A Problem Like Maria: Gender and Sexuality in the American Musical. Ann Arbor: University of Michigan Press. 